Fixed Point Theory, 20(2019), No. 1, 135-156

DOI: $10.24193 /$ fpt-ro.2019.1.08

http://www.math.ubbcluj.ro/ nodeacj/sfptcj.html

\title{
FIXED POINT APPROACH TO THE STABILITY OF GENERALIZED POLYNOMIALS
}

\author{
DAN M. DĂIANU \\ Politehnica University of Timişoara, Piaţa Victoriei No. 2, 300006 Timişoara, Romania \\ E-mail: dan.daianu@upt.ro \\ Dedicated to Professor Ioan A. Rus
}

\begin{abstract}
Using a new fixed point theorem for linear operators which act on function spaces, we give an iterative method for proving the generalized stability in three essential cases and the hyperstability for polynomial equation $\Delta_{y}^{n+1} f(x)=0$ on commutative monoids. The proposed iterative fixed point method leads to final concrete unitary estimates, and also improves and complements the known stability results for generalized polynomials.

Key Words and Phrases: Stability, hyperstability, fixed point method, generalized polynomial. 2010 Mathematics Subject Classification: 39B82, 39B72, 39B62, 47H10.
\end{abstract}

Acknowledgement. The author thanks the reviewers for their helpful suggestions.

\section{REFERENCES}

[1] M. Albert, J. Baker, Functions with bounded nth differences, Ann. Polon. Math., 43(1983), 93-103.

[2] J.M. Almira, A.J. López-Moreno, On solutions of the Fréchet functional equation, J. Math. Anal. Appl. 332(2007), no. 2, 1119-1133.

[3] A. Bahyrycz, J. Brzdęk, M. Piszczek, J. Sikorska, Hyperstability of the Fréchet Equation and a Characterization of Inner Product Spaces, J. Funct. Spaces Appl., 2013(2013).

[4] J.A. Baker, The stability of certain functional equations, Proc. Amer. Math. Soc., 112(1991), no. $3,729-732$.

[5] J. Brzdęk, K. Ciepliński, Hyperstability and Superstability, Abstr. Appl. Anal., 2013(2013).

[6] J. Brzdȩk, L. Cădariu, K. Ciepliński, Fixed Point Theory and the Ulam Stability, J. Funct. Spaces Appl., 2014(2014).

[7] L. Cădariu, L. Găvruţa, P. Găvruţa, Fixed points and generalized Hyers-Ulam stability, Abstr. Appl. Anal., 2012(2012).

[8] D.M. Dăianu, Recursive procedure in the stability of Fréchet polynomials, Adv. Difference Equ., 16(2014).

[9] D.M. Dăianu, A stability criterion for Fréchet's first polynomial equation, Aequationes Math. 88(2014), no. 3, 233-241.

[10] D.H. Hyers, On the stability of the linear functional equation, Proc. Nat. Acad. Sci. USA, $\mathbf{2 7}(1941), 222-224$.

[11] H. Khodaei, Hyperstability of the Generalized Polynomial Functional Equation of Degree 5, Mediterr. J. Math., 13(2016), no. 4, 1829-1840. 
[12] A. Marchaud, Sur les dérivées et sur les différences des fonctions de variables réelles, J. Math. Pures Appl., 6(1927), no. 9, 337-426.

[13] A. Pringsheim, Zur theorie der zweifach unendlichen Zahlenfolgen, Math. Ann., 53(1900), 289321.

[14] Th.M. Rassias (ed.), Handbook of Functional Equations: Stability Theory, Springer Optimization and Its Applications, 96, 2014.

[15] L. Székelyhidi, Discrete Spectral Synthesis and Its Applications, Springer, Dordrecht, 2006.

Received: April 7, 2016; Accepted: February 23, $201 \%$. 
